\title{
QUALITY ATTRIBUTES OF COOKIES FORTIFIED WITH DATE POWDER
}

Aya A. Amin ${ }^{1 *}$, El-kalyoubi ${ }^{2}$ M., El-Sharabasy ${ }^{1}$ S.F. and Abdel-Fattah ${ }^{2}$ A.A.

1- Center Lab. for Date Palm Res. and Development, Agric. Research Center, Giza, Egypt

2- Food Sci. Dept., Fac. of Agric., Ain Shams Univ., P.O. Box 68, Hadayek Shobra 11241, Cairo, Egypt

\section{*Corresponding author: aya.nasser.amin@gamil.com}

Received 9 December, 2019

Accepted 12 January, 2020

\begin{abstract}
Date palms (Phoenix dactylifera L.) are important traditional crop, vital component of human diet in the Arab world. It has essential nutrients i.e. (vitamins, minerals, dietary fibers and carbohydrates) and potential health benefits. Date fruit was oven dried and milled. This study aims to evaluate the effect of date powder as a natural sweetener instead of sugar on the proximate chemical composition, physical properties and sensory characterizations of cookies. However, levels of replacement of Samany date powder which used in the cookies formula were 5, 10, 20 and $40 \%$. Proximate chemical composition of Samany date were determined .It was noticed that the moisture percentage was of $54.74 \%$, while the protein and fat contents were found at low levels being 1.61 and $0.77 \%$, respectively. The ash and crude fiber were constituted 2.36 and $6.51 \%$, respectively. Total sugars were obtained at $47.27 \%$, however, reducing and non - reducing sugar were given at 35.40 and $11.87 \%$, respectively. The obtained results showed that increasing the date powder ratio led to increase total carbohydrates, crude fibers, ash, crude fat, moisture and protein contents. However, physical characteristics of cookies, i.e. thickness, diameter and speed factor of the prepared cookies decreased. The results of organoleptic criteria indicated that color had low score with increasing the substitution ratio. On the other hand, both crispiness and texture were affected at $20 \%$ and $40 \%$ of date powder level. Our findings ascertained that the cookies supplemental with $40 \%$ date powder had the lowest acceptability. Meanwhile, at substitution ratio of $10 \%$, the quality of cookies was not adversely affected by the color, taste, crispiness, texture, odor and overall acceptability ( $p \geq 0.05$ ), so, it could be suggesting that date palm powder
\end{abstract}

can be used and incorporated in bakery products up to $10 \%$.Finally, it can be concluded that it is highly recommended to use dates powder in the manufacturing of cookies at a commercial scale where the nutritional value of the samples increased by increasing the replacement of date powder.

Keywords: Date palm, Quality of cookies, Chemical composition, Physical properties, Sensory attributes

\section{INTRODUCTION}

Date palm (Phoenix dactylifera L.) is one of the most important cultivates grown in the world .It has a high nutritive value and it is excellent source of minerals, dietary fiber and other beneficial healthy metabolites Baliga et al (2011). The mature date fruits could be classified into three groups depending on its moisture content i.e., soft date type (>50\% moisture) semi dry type (24-50\% moisture) and dry type (<24\% moisture) according to Al-Shahib and Marshall, (2003). On the other hand, Egypt produces 1.5 million tons of dates annually being average 18 percent of the global production of 7.5 million tons according to FAO, (2017) and El-Sharabasy and Rizk, (2019).

In Egypt, date palms are distributed in the Nile valley, Oases and desert including soft dates such as Zaghloul, Samany, Hayany and Amhat; semi dry dates (Al-amri, saidy or siwi) and dry dates i.e. Sakouti, Ebrimi and Barakawi Mohammed, (2000).

Date fruits characterized by its higher content of essential nutrients such as carbohydrates, total sugar, minerals, phytochemicals i.e. sterols, phenolic components, carotenoids andflavonoids, which these increase the nutritional and sensory properties of palm dates and possess multiple 
beneficial and healthy effects. The dates contain a high percentage of carbohydrate (total sugars, 44$88 \%)$, fat $(0.2-0.5 \%)$, protein $(2.3-5.6 \%)$ and a high percentage of dietary fiber $(6.4-11.5 \%)$ as well as high concentration of minerals and vitamins. On the other hand, the high production potential of dates worldwide, it may not be possible to consumption on these freshly harvested fruit so, recent studies enhanced its applications in food industries and develop the functional foods Al-Shahib and Marshall, (2003); El-Hadrami et al (2011); Handa et al (2012) and Dayang et al (2014).

The objective of our study was to evaluate the proximate chemical composition of Samany date as well as the quality attributes of prepared cookies enriched with date powder as a replacer with sugar at different ratios (5, 10, 20 and 40\%).

\section{MATERIALS AND METHODS}

\section{Materials}

Date Palm (Phoenix dactylifera L.) fruits (variety Samany, season 2017) were purchased from El-Obour market, Egypt, at Rutab stage (about $30 \%$ moisture).

Ingredients for cookies dough (wheatflour, egg, salt, margarine, baking powder and sugar) were obtained from the local market, Cairo, Egypt.

\section{Methods}

\section{Technological treatments}

\section{Preparation of Samany date powder}

Samany date were washed to remove any adhering dirts, followed by removing of the seeds and the pulp was then oven dried at $75 \pm 1^{\circ} \mathrm{C}$ until constant weight. The dried date was milled using hand milling (M-20, IKA-Werke, GMBH \& CO. KG, Staufen, Germany) for 2 min. The powder was packed in polyethylene bags and stored at room temperature until it used.

\section{Processing of cookies}

Cookies samples were prepared using Samany date powder as sugar replacer at ratios of 5, 10, 20 and $40 \%$ in cookies batter formula as shown in Table (1). The flours, sugar, margarine, eggs and salt were mixed together manually for $4 \mathrm{~min}$ .the dough was rolled out and cut to cookies piec- es having 36 min diameter and placed in trays. Baking was done at $225 \pm 7^{\circ} \mathrm{C}$ for $10-12 \mathrm{~min}$. and cool at room temperature for $8-10 \mathrm{~min}$ (AACC, 2000).

\section{Analytical Methods}

\section{Proximate Chemical composition}

Moisture, protein, fat, ash, crude fibers, reducing and none reducing sugars were determined according to the AOAC, (2007). Mineral elements (potassium, magnesium, iron, sodium, phosphorus and copper) were also measured using the atomic absorption Spectrophotometer .Total carbohydrates were measured by difference between 100 and the summation of other proximate parameters as Nitrogen free extract (NFE) percentage carbohydrate.

$\%$ Carbohydrate $($ NFE $)=100-(M+P+F+A+F 2)$

Where $\mathrm{M}=$ moisture, $\mathrm{P}=$ protein, $\mathrm{F}=$ fat, $\mathrm{A}=$ ash and $\mathrm{F} 2$ = crude fiber

Determination of sugar fractions for Samany date powder

Fractionation of mono and disaccharideswereanalyzed by High Performance Liquid Chromatography (HPLC) according to the AOAC, (2007).

Determination of vitamins for Samany date powder

Water soluble vitamins B and C were determined by HPLC according to Batifoulier et al (2005) and Romeu-Nadal et al (2006).

\section{Physical characteristics of cookies}

The method of AACC, (2000) was carried out for the determination of diameter (width), thickness and spread factor as follows:

\section{Diameter (D)}

Six cookies were placed edge to edge. The total diameter of the six pieces was measured in $\mathrm{mm}$ by using a ruler. The cookies were rotated at an angle of $90^{\circ}$ for duplicate reading. This was repeated once more and average value was reported. 
Table 1. Experimental cookies formula (gm)

\begin{tabular}{|c|c|c|c|c|c|c|}
\hline Treatments & Flour & Sugar & date powder & shortening & Eggs & Baking powder \\
\hline Control & 100 & 50 & 0 & 50 & 0.5 & 2 \\
F1 & 100 & 47.5 & 2.5 & 50 & 0.5 & 2 \\
F2 & 100 & 45 & 5 & 50 & 0.5 & 2 \\
F3 & 100 & 40 & 10 & 50 & 0.5 & 2 \\
F4 & 100 & 30 & 20 & 50 & 0.5 & 2 \\
\hline
\end{tabular}

Treatments $=\mathrm{F} 1=5 \%$ date powder, $\mathrm{F} 2=10 \%$ date powder, $\mathrm{F} 3=20 \%$ date powder and $\mathrm{F} 4=40$

$\%$ date powder

\section{Thickness (T)}

Six cookies were placed on top of another one. The total height was measured in $\mathrm{mm}$ with ruler. This process was repeated once more and the thickness average was reported.

\section{Spread factor (SF)}

The spread factor was calculated from the diameter and thickness using the following equation:

\section{$S F=D / T \times C F X 10$}

Where:

$\mathrm{D}$ : diameter; $\mathrm{T}$ : thickness and CF is a correction factor at constant atmospheric pressure, it value was 1.0 in the case.

\section{Sensory evaluation}

To assess the quality attributes and acceptability of the prepared samples, 10 trained panel panelist from staff of the Center Laboratory for Date palm Researches and Development, Agriculture Research Center, Giza, Egypt. The sensory attributes of color, taste, texture, odor, crispiness and overall acceptability using the scale degree from zero to ten .The key of score was $6-10=$ excellent, $5=$ very good, $4=$ good,3=fair, $2=$ poor and zero $1=$ very poor according to Handa et al (2012).

\section{Statistical analyses}

Statistical comparisons were done with Duncan's test using the SPSS program (SPSS for Windows, Version Rel. 10.0.5., 1999, SPSS Inc.,) Significance level of $P>0.05$ was considered to be significant (Snedecor and Cochran, 1980). The obtained data were carried out in triplicates, unless otherwise stated.

\section{RESULTS AND DISCUSSION}

\section{Proximate Chemical composition}

The obtained results of chemical constitutes for Samany date are shown in Table (2), It could be noticed that moisture content was being $54.74 \%$, while protein and lipids and tannins constituted low levels being 1.61, 0.77 and $0.75 \%$, respectively. As for ash and crude fiber, their contents were 2.36 and $6.51 \%$, respectively. Date proved that total carbohydrates were at $88.75 \%$, meanwhile, reducing and non - reducing sugars were given at 35.40 and $11.87 \%$, respectively. From our results, it could be mention that Samany date characterized by its higher content of ash, crude fiber, total sugar and reducing sugar. So these findings are agree with that of Osman, (2008); Sakr et al (2010) and Moustafa et al (1986). 
Table 2. Proximate composition of Samany Date palm $(\mathrm{g} / 100 \mathrm{~g}$ on dry weight basis \%)

\begin{tabular}{|l|c|}
\hline Proximate composition & Samany Date palm \\
\hline Moisture & $54.74 \pm 3.11$ \\
Protein & $1.61 \pm 0.09$ \\
Fat & $0.77 \pm 0.03$ \\
Ash & $2.36 \pm 0.06$ \\
Crude fiber & $6.51 \pm 1.95$ \\
Total carbohydrate* & $34.92 \pm 1.36$ \\
Tannins & $0.75 \pm 0.12$ \\
Total sugar & $47.27 \pm 1.31$ \\
Reducing sugar & $35.40 \pm 1.31$ \\
Non reducing sugar & $11.87 \pm 0.42$ \\
\hline
\end{tabular}

${ }^{*}$ Calculated by difference .values are means \pm standard deviations $(n=3)$.

the elements analysis of Samany date sample showed that it characterized by higher contain of potassium (51.94 $\mathrm{mg} / 100 \mathrm{~g}$ ), phosphorus (21.79 $\mathrm{mg} / 100 \mathrm{~g})$, sodium $(13.4779 \mathrm{mg} / 100 \mathrm{~g})$, followed by magnesium(5.0979mg/100g) and copper (3.46 $79 \mathrm{mg} / 100 \mathrm{~g}$ ) .as shown in Table (3). These minerals are important factor health. These results are in agreement with that reported by El-Sohaimy and Hafez, (2010) and Ashraf and Hamidi-esfahani, (2011).

Table 3. Minerals Content of Samany Date (mg $/ 100 \mathrm{~g}$, on dry weight basis)

\begin{tabular}{|c|c|}
\hline Minerals & Content in Samany Date \\
\hline $\mathrm{K}$ & $51.94 \pm 0.82$ \\
$\mathrm{Fe}$ & $1.56 \pm 0.38$ \\
$\mathrm{Mg}$ & $5.09 \pm 0.43$ \\
$\mathrm{Cu}$ & $3.46 \pm 0.20$ \\
$\mathrm{Na}$ & $13.47 \pm 0.20$ \\
$\mathrm{P}$ & $21.79 \pm 0.70$ \\
\hline
\end{tabular}

Values are means \pm standard deviations $(n=3)$.

The High Performance Liquid Chromatography (HPLC) analysis of sugar fractions indicated that the carbohydrate of Samany sample showed a high contents of glucose, fructose and sucrose at level of $7.89,5.44$ and $0.66 \%$, respectively, as shown in Table (4). On the other hand, minimum concentrations of other sugar fractions were observed, i.e. xylose, mannose, lactose and raffinose. These findings are in agree with that mentioned by Sulieman et al (2012).
Table 4. HPLC for sugar analysis of Samany date

\begin{tabular}{|l|c|}
\hline \multicolumn{1}{|c|}{ Saccharide } & Content (\%) \\
\hline Glucuronic & 0.034 \\
Raffinose & 0.246 \\
Sucrose & 0.660 \\
Lactose & 0.038 \\
Glucose & 7.898 \\
Xlylose & 0.011 \\
Galactose & 0.017 \\
L-Rhaminose & 0.031 \\
Mannose & 0.011 \\
Fructose & 5.439 \\
Manito & 0.011 \\
Sorbitol & 0.087 \\
Ribose & 0.007 \\
\hline
\end{tabular}

Date of The HPLC analysis for water soluble vitamins of Samany date showed that the vitamin $B$ COMPLEX group proved the descending trend as cyanocobalamin (B12), Folic acid (B9), Nicotinic acid (B3), Riboflavin (B2), Pyridoxine (B6) and Thiamine (B1) their concentrations were (128.56, 117.59, 24.55, 21.36, 20.76 and 18.69 ppm. consists of a large amount of and being (128.56 and $117.59 \mathrm{ppm})$. On the other hand, vitamin $\mathrm{C}$ content was 12.80 ppm as shown in Table (5). These results are agreed with that obtained by Aslam et al (2013). It could be mentioned supplementation for human diet.

Table 5. HPLC for vitamins analysis of Samany date

\begin{tabular}{|l|c|}
\hline Vitamins & Concentration (ppm) \\
\hline \multicolumn{2}{|l|}{ Vitamin B } \\
\hline Nicotinic acid(B3) & 24.55 \\
Thiamine(B1) & 18.69 \\
Folic acid(B9) & 117.59 \\
Pyridoxine (B6) & 20.76 \\
Riboflavin(B2) & 21.36 \\
cyanocobalamin (B12) & 128.56 \\
\hline Vitamin C \\
\hline Ascorbic acid & 12.80 \\
\hline
\end{tabular}


Proximate composition for cookies fortified with different ratios of Samany date powder

The effect of different ratios of Samany date powder on proximate chemical composition was studied in prepared cookies samples. The obtained results are shown in Table (6). It could be noticed that moisture content increased with increasing the date powder substitution. The high content of moisture is due to high sugar content in Samany date which binds water in fortified cookies, these findings are in the same line with Handa et al (2012). As for ash content, cookies samples showed the same trend with increment rate due to higher mineral content in Samany date fruits. Similar results were obtained for crude fibers as compared with the control sample. The fat content of cookies was noticed in fortified samples in comparison with control one. No significant differences ( $p$ $\geq 0.05$ ) were observed among all samples. The observed reduction in protein content could be due to the high gluten concentration in flour, which could have a diluting effect on protein as well as its lower content in date powder. The opposite trend was observed for total carbohydrates in fortified cookies samples with different levels of Samany date powder. The incorporation of date powder as replacer of sugar led to decrease in carbohydrates with increasing the substitution ratio. The obtained results are in line with that of Peter Ikechukwu et al (2017).

It could be observed that the addition of date palm powder in flour is of nutritional importance of cookies for children and other consumers Guo et al (2014) and Sudha et al (2007).

Table 6. Proximate composition for cookies as affected ratios of Samany date powder

\begin{tabular}{|c|c|c|c|c|c|c|}
\hline Treatments & Moisture & Ash & Protein & Crude fibers & Crude fat & $\begin{array}{c}\text { Total } \\
\text { carbohydrates }^{*}\end{array}$ \\
\hline Control & $6.88 \mathrm{a} \pm 0.01$ & $1.31 \mathrm{a} \pm 0.03$ & $6.39 \mathrm{a} \pm 0.02$ & $2.33 \mathrm{a} \pm 0.15$ & $4.48 \mathrm{a} \pm 0.19$ & $78.61 \mathrm{a} \pm 0.08$ \\
F1 & $7.40 \mathrm{a} \pm 0.07$ & $1.29 \mathrm{a} \pm 0.02$ & $6.56 \mathrm{a} \pm 0.05$ & $6.73 \mathrm{a} \pm 0.06$ & $4.99 \mathrm{a} \pm 0.04$ & $73.03 \mathrm{a} \pm 0.08$ \\
F2 & $7.92 \mathrm{a} \pm 0.01$ & $1.38 \mathrm{a} \pm 0.03$ & $6.46 \mathrm{a} \pm 0.06$ & $6.90 \mathrm{a} \pm 0.18$ & $5.30 \mathrm{a} \pm 0.06$ & $71.87 \mathrm{a} \pm 0.33$ \\
F3 & $8.19 \mathrm{a} \pm 0.10$ & $1.52 \mathrm{a} \pm 0.08$ & $6.39 \mathrm{a} \pm 0.09$ & $7.86 \mathrm{a} \pm 0.06$ & $6.02 \mathrm{a} \pm 0.03$ & $69.72 \mathrm{a} \pm 0.24$ \\
F4 & $8.50 \mathrm{a} \pm 0.02$ & $1.65 \mathrm{a} \pm 0.03$ & $6.37 \mathrm{a} \pm 0.62$ & $9.17 \mathrm{a} \pm 0.15$ & $6.30 \mathrm{a} \pm 0.06$ & $68.01 \mathrm{a} \pm 0.37$ \\
\hline
\end{tabular}

${ }^{*}$ Calculated by difference. Values are means \pm standard deviations $(n=3)$.

Treatments $=\mathrm{F} 1=5 \%$ date powder, F2 $=10 \%$ date powder, $\mathrm{F} 3=20 \%$ date powder and F4 $=40 \%$ date powder.

\section{Physical characteristics of cookies}

Mean values of physical parameters for prepared cookies samples by substituting sugar with date powder at different levels are shown in Table (7). No significant effect was noticed among all samples concerning thickness of cookies $(p \geq 0.05)$, however, the less thick of cookies led to the lesser of its ability to withstand stress. Values of thickness ranged between $1.024-1.091 \mathrm{~cm}$ with slight decrease when the date replacement was increased .As for cookies diameter, it could be observed that its values decreased in the treated samples in comparison with the control. So, the addition of date palm powder in the recipe of cookies affected its diameter valueswith a decrement trend when the incorporation increased. On the other hand, the spread ratio ranged between 4.16 - 4.43in treated samples as compared with the control. The higher value of spread ratio was noticed in samples as the incorporationdecreased, so, this may be due to higher solubility of sucrose sugar, hence, the increasing of date powder in dough recipe decreased the diameter and spread ratios. It is noteworthy that cookies having higher spread ratio are considered most desirable quality attributes, therefore, samples with $10 \%$ incorporation was the most desirable one. These findings are in the harmony with those of Hooda and Jood, (2005), Handa et al (2012), Alsenaien et al (2015) and Peter Ikechukwu et al (2017). 
Table 7. Effect of different levels of Samany date powder on physical parameters of cookies

\begin{tabular}{|c|c|c|c|}
\hline Treatments & $\begin{array}{c}\text { Thickness } \\
(\mathbf{m m})\end{array}$ & $\begin{array}{c}\text { Diameter } \\
(\mathbf{m m})\end{array}$ & $\begin{array}{c}\text { Spread ratio } \\
(\%)\end{array}$ \\
\hline Control & $10.91^{\mathrm{a}} \pm 0.08$ & $47.67^{\mathrm{a}} \pm 0.29$ & $4.37^{\mathrm{a}} \pm 0.03$ \\
F1 & $10.40^{\mathrm{a}} \pm 0.06$ & $46.11^{\mathrm{ab}} \pm 0.49$ & $4.43^{\mathrm{a}} \pm 0.04$ \\
F2 & $10.35^{\mathrm{a}} \pm 0.81$ & $45.25^{\mathrm{bc}} \pm 0.24$ & $4.39^{\mathrm{a}} \pm 0.37$ \\
F3 & $10.30^{\mathrm{a}} \pm 0.09$ & $44.11^{\mathrm{cd}} \pm 0.23$ & $4.28^{\mathrm{a}} \pm 0.06$ \\
F4 & $10.24^{\mathrm{a}} \pm 0.04$ & $42.55^{\mathrm{d}} \pm 1.97$ & $4.16^{\mathrm{a}} \pm 0.18$ \\
\hline
\end{tabular}

Values represent mean \pm SEM. $n=3$. Values of the same row with different superscripts are significant $(p \leq 0.05)$. Treatments $=F 1=5 \%$ date powder, $F 2=10 \%$ date powder, $F 3=20 \%$ date powder and $\mathrm{F} 4=40 \%$ date powder.

\section{Sensory evaluation for cookies}

Data in Table (8) shows the sensory scores of prepared cookies as affected by substituting sugar with Samany date powder. It could be mentioned that samples with $5 \%$ and $10 \%$ of date palm revealed the highest score for all sensory parameters as shown in the table in comparison with the control .However, increasing the date incorporation recipe dough rated the lower scores by panelists for cookies. The obtained results are agree with those of Fahloul et al (2010) and Handa et al (2012). Color had the low scores as a result of increasing substitution above $10 \%$, however, the darker color could be due to the high sugar content which reacted with heat during baking Peter Ikechukwu et al (2017). The obtained results revealed that increasing date powder level decreased the cookies hardness, crispiness and texture of cookies .Samples obtained from $40 \%$ date powder had the lowest sensory acceptance.

The obtained results for the panelist attributes (organolyptic parameters) for prepared cookies indicated that date powder could be replaced up to $10 \%$ in cookies formulation without affecting their quality properties.

Table 8. Sensory attributes of cookies as affected by substitution of Samany date powder

\begin{tabular}{|c|c|c|c|c|c|c|}
\hline Treatments & Color & Taste & Crispiness & Texture & Odor & $\begin{array}{c}\text { Over all } \\
\text { acceptability }\end{array}$ \\
\hline Control & $7.55^{\mathrm{a}} \pm 2.54$ & $7.27^{\mathrm{ab}} \pm 2.28$ & $6.82^{\mathrm{a}} \pm 2.14$ & $7.05^{\mathrm{a}} \pm 2.35$ & $7.91^{\mathrm{c}} \pm 0.70$ & $9.36^{\mathrm{a}} \pm 1.63$ \\
F1 & $7.82^{\mathrm{a}} \pm 2.70$ & $8.00^{\mathrm{ab}} \pm 2.28$ & $8.50^{\mathrm{a}} \pm 1.63$ & $7.00 \mathrm{a} \pm 2.23$ & $9.00^{\mathrm{ab} \pm 0.89}$ & $8.64^{\mathrm{ab}} \pm 0.89$ \\
F2 & $7.91^{\mathrm{a}} \pm 2.64$ & $8.50^{\mathrm{a}} \pm 1.16$ & $7.66^{\mathrm{a}} \pm 1.59$ & $6.64 \mathrm{a} \pm 1.69$ & $8.27^{\mathrm{ab} \pm 1.19}$ & $9.00^{\mathrm{ab} \pm 1.36}$ \\
F3 & $7.00^{\mathrm{a}} \pm 2.68$ & $6.91^{\mathrm{ab}} \pm 2.66$ & $7.36^{\mathrm{a}} \pm 2.29$ & $6.32 \mathrm{a} \pm 2.27$ & $9.45^{\mathrm{a}} \pm 0.52$ & $7.77^{\mathrm{b}} \pm 1.86$ \\
F4 & $7.00^{\mathrm{a}} \pm 2.68$ & $6.18^{\mathrm{b}} \pm 2.64$ & $7.27^{\mathrm{a}} \pm 1.79$ & $6.14 \mathrm{a} \pm 2.54$ & $8.55^{\mathrm{ab} \pm 1.04}$ & $6.27^{\mathrm{c}} \pm 1.95$ \\
\hline
\end{tabular}

Values represent mean \pm SEM. $n=10$. Values of the same row with different superscripts are significantly different $(p \leq$ 0.05). Treatments $=F 1=5 \%$ date powder, F2 = $10 \%$ date powder, F3 = $20 \%$ date powder and F4 = 40 \% date powder. 


\section{REFERENCES}

AACC. 2000. American Association of Cereal Chemists. Approved Methods of the AACC. $10^{\text {th }}$ ed. American Association of Cereal Chemists, St., Paul, Minnesota, USA.

Alsenaien W.A., Alamer R.A., Tang Z.X. and Albahrani S.A. 2015. Substitution of Sugar with Dates Powder and Dates Syrup in Cookies Making. Advance J. of Food Sci. and Technology, 8(1), 8-13.

Al-Shahib W. and Marshall R.J. 2003. The fruit of the date palm: Its possible use as the best food for the future? Int. J. Food Sci. Nutri., 54(4), 247-259.

A.O.A.C. 2007. Association of Official Analytical Chemists Official Methods of Analysis $17^{\text {th }}$ Edition, Gaithersburg, Maryland, USA.

Ashraf Z. and Hamidi-Esfahani Z. 2011. Date and date processing: A review. Food Reviews International, 27, 101-133.

Aslam J., Khan S.H. and Khan S.A. 2013. Quantification of water soluble vitamins in six date palm (Phoenix dactylifera L.) cultivar's fruits growing in Dubai, United Arab Emirates, through high performance liquid chromatography. J. of Saudi Chemical Society, 17, 916.

Baliga M.S., Baliga B.R.V., Kandathil S.M., Bhat H.P. and Vayalil P.K. 2011. A review of the chemistry and pharmacology of the date fruits (Phoenix dactylifera L.). Food Research International; 44, 1812-1822.

Batifoulier F., Verny M.A., Besson C., Demigné C. and Rémésy C. 2005. Determination of thiamine and its phosphate esters in rat tissues analyzed as thiochromes on a RP-amide C16 column. J. Chromatogr. B Anal. Technol. Biomed. Life Sci., 816(1-2), 67-72.

Dayang J.F., Reuben C.R. and Raji F. 2014. Nutritional, socioeconomic and health benefits of dates. Int. J. Food Nutr. Sci., 3, 63-73.

El-Hadrami A., Daayf F. and El-Hadrami I. 2011. Secondary metabolites of date palm. In: Date Palm Biotechnology Jain S.M., Al-Khayri J.M. and Johnson D.V. (Eds.). Springer, Netherlands, pp. 653-674.

El-Sharabasy S.F. and Rizk R.M. 2019. Atlas of date palm in Egypt. Food and Agric. Organization of the United Nations, Cairo, Egypt, 9 p.
El-Sohaimy S.A. and Hafez E.E. 2010. Biochemical and Nutritional Characterizations of Date Palm Fruits (Phoenix dactylifera L.). J. of Applied Sci. Research, 6(8), 1060-1067.

Fahloul D., Abdedaim M. and Trystram G. 2010. Heat, mass transfer and physical properties of biscuits enriched with date powder. J. of Applied Sci. Research, 6(11), 1680-1686.

FAO 2017. "Agriculture Data," FAOSTAT, Last Accessed.

http://faostat.fao.org/faostat/collections?subset $=$ agriculture.

Guo M.M., Du J.H., Zhang Z.A., Zhang K.L. and Jin Y.H. 2014. Optimization of brewer's spent grain-enriched biscuits processing formula. J. Food Process Eng., 37, 122-130.

Handa C., Goomer S. and Siddhu A. 2012. Physicochemical properties and sensory evaluation of fructoligosaccharide enriched cookies. J. Food Sci. Technol., 49(2), 192-199.

Hooda S. and Jood S. 2005. Organoleptic and nutritional evaluation of wheat biscuits supplemented with untreated and treated fenugreek flour. Food Chemistry; 90, 427-435.

Mohamed A.A. 2000. Palm culture and production of dates In Sudan. A country report, Palm and Dates Research Centre, Sudan. Cited fromRamadan B.R., El-Rify M.N.A., Abd El-Hamid A.A. and Ab El-Majeed M.H. 2016. Effect of some treatments on chemical composition and quality properties of Saidy date fruit (Phoenix dactylifera L.) during storage. Assiut. J. Agric. Sci., 47(5), 107-124.

Moustafa A.A., El-Aidy A.A. and El-Sammak A.P. 1986. Evaluation of two seedling date palms grown in El-Wady El-Gedid in comparison to standard cultivar "Heigazy". Proceeding of the Second Symposium on the Date Palm in Saudi Arabia Al-Hassa, Saudi Arabia, King Faisal Univ., pp. 153-161.

Osman S.M. 2008. Fruit Quality and General Evaluation of Zaghloul and Samany Date Palms Cultivars Grown under Conditions of Aswan. American-Eurasian J. Agric. \& Environ. Sci., 4(2), 230-236.

Peter Ikechukwu A., Okafor D.C., Kabuo N.O., Ibeabuchi J.C., Odimegwu E.N., Alagbaoso S.O. and Mbah R.N. 2017. Production and evaluation of cookies from whole wheat and date palm fruit pulp as Sugar Substitute. Int. J. of Advancement in Eng. Technology, Management and Applied Sci., 4, 2349-3224. 
Romeu-Nadal M., Morera-Pons S., Castellote A.I. and Lopez-Sabater M.C. 2006. Rapid high-performance liquid chromatographic method for Vitamin $\mathrm{C}$ determination in human milk versus an enzymatic method. J. of Chromatography B; 830, 41-46.

Sakr M.M., Abu-Zeid I.M., Hassan A.E., Baz A.G.I.O. and Hassan W.M. 2010. Identification of some date palm (Phoenix dactylifera) cultivars by fruit characters. Indian J. of Sci., and Technology, 3(3), 111-115.
Snedecor G.W. and Cochran W.G. 1980. Statistical methods $7^{\text {th }}$ ed. Lowa State Univ., Press, Ames, lowa, USA.

Sudha M.H., Vetrimani R. and Leelavathi K. 2007. Influence of fibre from different cereals on the rheological characteristics of wheat flour dough and on biscuit quality. Food Chem., 100, 1365-1370.

Sulieman E.A., Abd-Elhafise I.A. and Abdelrahim M.A. 2012. Comparative Study on Five Sudanese Date (Phoenix dactylifera L.). Fruit Cultivars. Food and Nutrition Sci., 3, 1245-1251. 
مجلة اتحاد الجامعات العربية للعلوم الزراعية، جامعة عين شمس، القاهرة، مصر مجلا(27)، عدد(5)، 2547-2539، 2019

Website: http://ajs.journals.ekb.eg

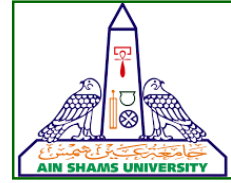

2547

\section{صفات الجودة للكوكيز المدعمة ببودر التمر}

[201]

$$
\text { ايه عبد الناصر امين1" - - ممدوح القليوبى2 - شريف فتحى الثرباصى } 1 \text { - الفتاح عبد الكريم عبد الفتاح2 }
$$

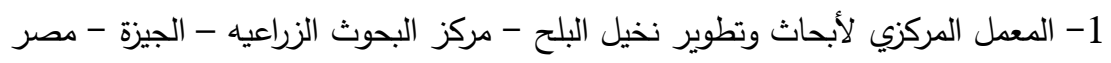

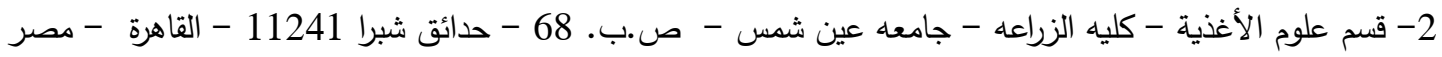

*Corresponding author: aya.nasser.amin@gamil.com

Received 9 December, 2019 Accepted 12 January, 2020

انخفض السمك والقطر وسرعة الإنتشار للكوكيز

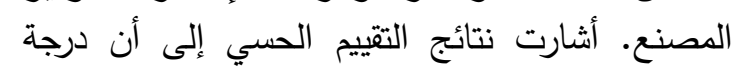

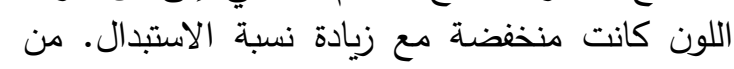

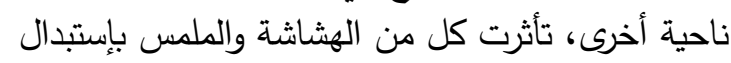

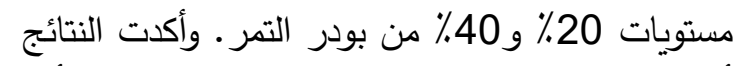

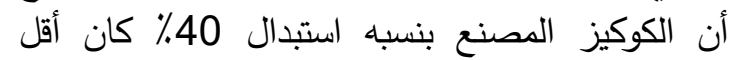

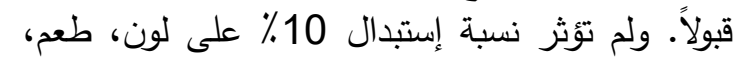

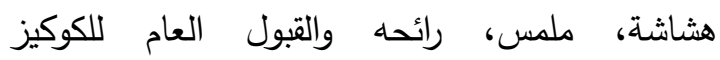

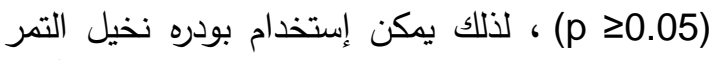

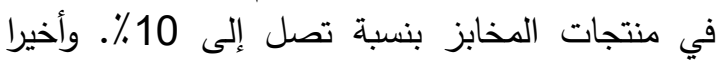
يوصى بإستخدام بودر التمر في تصنيع الكوكيز على الفى

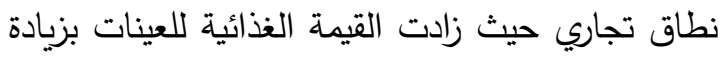

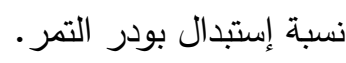

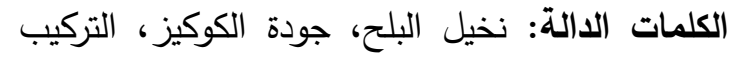

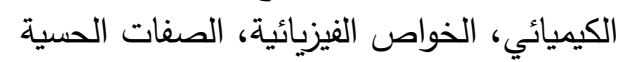

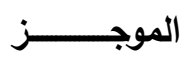

تهدف هذه الدراسة إلى تقييم تأثير مسحوق التمور

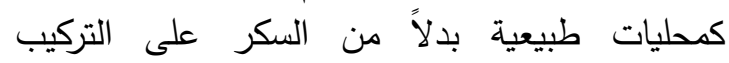

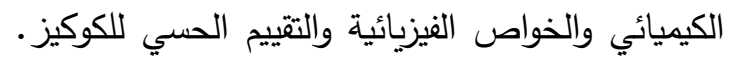

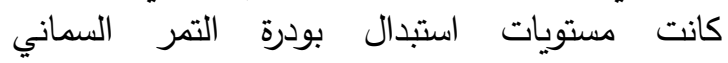

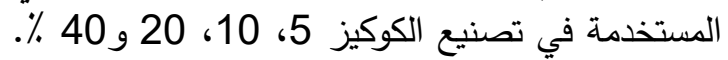

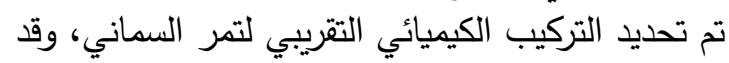

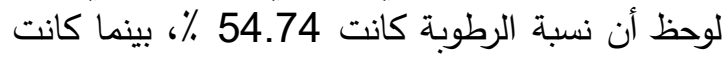
محتويات البروتين والدهون بمستويات منخفضة كانت وكانت

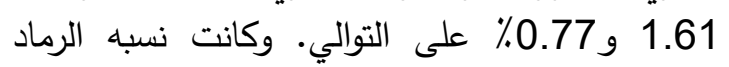

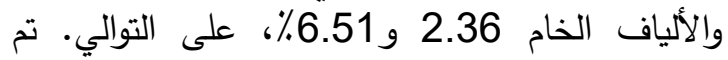

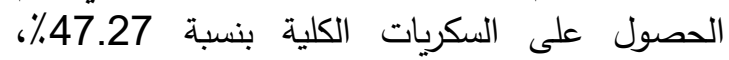

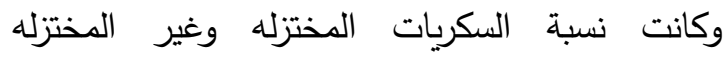

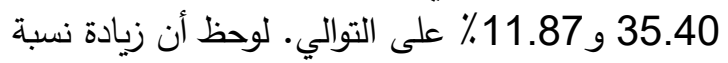

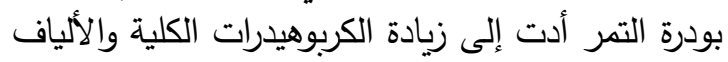

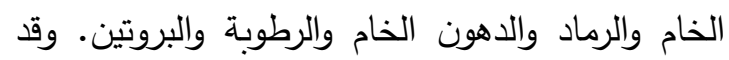

